\title{
PEDAGOGY
}

\section{TRAINING. THEORY AND METHODOLOGY OF THE USE OF TRAINING FORMS}

\author{
Doctor of Pedagogics, professor Bezlyudniy Oleksandr, \\ Doctor of Pedagogics, professor Komar Olga, \\ Ph.D. (Linguistics), associate professor Komar Oleh, \\ PavloTychyna Uman State Pedagogical University
}

DOI: https://doi.org/10.31435/rsglobal_ijitss/30042019/6456

\section{ARTICLE INFO}

Received 18 February 2019

Accepted 20 April 2019

Published 30 April 2019

\section{KEYWORDS}

training, use of training forms, interpersonal communication.

\begin{abstract}
The article deals with the use of training forms while teaching students by means of interactive technologies. Every graduate of pedagogical educational establishments, who has certain knowledge of general, age psychology and personality psychology, should be familiar with training as a form of class conduction. It is desirable to conduct classes in the form of training at higher education establishments, since it is a means of influence aimed at developing knowledge, social competence, skills and experience in the sphere of interpersonal communication; development of communicational competence, which is a factor of proficiency.
\end{abstract}

Citation: Bezlyudniy Oleksandr, Komar Olga, Komar Oleh. (2019) Training. Theory and Methodology of the Use of Training Forms. International Journal of Innovative Technologies in Social Science. 3(15). doi: 10.31435/rsglobal_ijitss/30042019/6456

Copyright: (c) 2019 Bezlyudniy Oleksandr, Komar Olga, Komar Oleh. This is an open-access article distributed under the terms of the Creative Commons Attribution License (CC BY). The use, distribution or reproduction in other forums is permitted, provided the original author(s) or licensor are credited and that the original publication in this journal is cited, in accordance with accepted academic practice. No use, distribution or reproduction is permitted which does not comply with these terms.

Застосування інтерактивної технології у навчанні студентів дозволяє майбутньому вчителевю початкової школи виступити в ролі активного суб'єкта педагогічної взаємодії, здатного самостійно організовувати свою діяльність специфічно направленою на розв'язання конкретних професійно-орієнтованих завдань.

Аби забезпечити ефективне оволодіння студентами інтерактивною технологією, бажано застосування групового навчального тренінгу, що відіграє особливу роль серед інтерактивних форм навчання і виховання. Тренінг усе частіше використовують у своій роботі не тільки професійні психологи, а й педагоги (звичайні викладачі, вихователі), соціальні працівники тощо. 3 тренінгом як формою занять має бути знайомий будь-який випускник педагогічного закладу, що має певні знання з загальної, вікової психології та психології особистості, оскільки вивчає предмет «Психологія», тому заняття зі студентами із засвоєння інтерактивної технології бажано також проводити у формі тренінгу.

Тренінг походить від англійського to train, що означає «навчати, тренувати, дресирувати». I. Авдєєва та I. Мельникова пояснюють, що «Термін «тренінг» (від англ. train, training) має ряд значень: навчання, виховання, тренування, дресирування» [1, 128]. Багатозначність визначень притаманна і науковим визначенням тренінгу. У вітчизняній психології поширені визначення тренінгу як одного з активних методів навчання, соціальнопсихологічного впливу. Соціально-психологічний тренінг за Ю. Смельяновим - це активне соціально-психологічне навчання, модель для вивчення соціально-психологічних явищ плюс практична лабораторія для формування комунікативних умінь, найбільш важливих в тому чи тому виді професійної діяльності [2]. Так Г. Ковальов [3] відносить тренінг до методів активного соціально-психологічного навчання як комплексного соціально-дидактичного 
напряму. Л. Петровська розглядає тренінг як «засіб впливу, спрямований на розвиток знань, соціальних настанов, умінь і досвіду в галузі міжособистісного спілкування, засіб розвитку компетентності в спілкуванні» [7]. Б. Паригін пояснює «як активне групове навчання навичкам спілкування в житті і суспільстві взагалі: від навчання професійно корисним навичкам до адаптації до нової соціальної ролі з відповідною корекцією Я - концепції і самооцінки» [6]. С. Макшанов серед безлічі пояснень, які відносяться до динаміки феноменів людини і групи, відображає процесуальні і продуктивні характеристики тренінгу, підкреслює «суб’єкт суб'єктний характер тренінгу, ефективність якого пов'язана 3 прийняттям відповідальності за все, що відбувається під час тренінгу, як фахівцем, що проводить тренінг, так і учасником»[4]. Наведемо висновки, які роблять I. Авдєєва та I. Мельникова: «...Тренінг - це багатофункціональний метод навмисних змін психологічних феноменів людини, групи й організації з метою гармонізації професійного й особистісного буття людини» [1, с.129]. Ми спирались на твердження і висновки наведених вище фахівців-психологів.

На думку вчених, тренінг - це одночасно:

- цікавий процес пізнання себе та інших;

- спілкування;

- ефективна форма опанування знань;

- інструмент для формування умінь та навичок;

- форма розширення досвіду [5, с.5].

Велику теоретичну цінність і практичну значимість у дослідженні проблеми тренінгу мають праці психологів і педагогів І. Авдєєвої, Д. Джонсона, Т. Зайцевої, Ю. Смельянова, Г. Ковальова, Д. Лі, С. Макшанова, Г. Марасанова, І. Мельникової, К. Мілютіної, Г. Моніної, Л. Панченко, Б. Паригіна, Л. Петровської, Н. Хмель та ін.

Якщо основна мета тренінгу - навчити конкретних навичок і вмінь, він стає частиною процесу навчання або професійної адаптації. Тренінг дає учасникам змогу не лише почути думку викладача чи подивитися на таблиці та схеми, а й практично застосувати отримані знання, перетворивши їх на вміння. Саме тому тренінгові форма роботи все ширше застосовується в сучасних системах навчання, а особливо навчання та перепідготовки дорослих.

Під час тренінгу створюється неформальне, невимушене спілкування, яке відкриває перед групою безліч варіантів розвитку і вирішення проблеми, заради якої вона зібралася. Як правило, учасники у захваті від тренінгових методів, оскільки вони роблять процес навчання цікавим, не обтяжливим i інформація, яка подається у формі тренінгу, як правило, запам'ятовується на досить високому рівні.

Традиційна форма навчання і тренінг мають суттєві відмінності. Традиційне навчання більше орієнтоване на правильну відповідь і за своєю сутністю $є$ формою передачі інформації на запитання і пошук. На відміну від традиційних, тренінгові форми навчання повністю охоплюють весь потенціал людини: рівень та розвиток ії компетентності (соціальної, емоційної та інтелектуальної), самостійність, здатність до прийняття рішень, взаємодії тощо. Звичайно, традиційна форма передачі знань не є сама по собі чимось негативним, проте в світі швидких змін і безперервного старіння знань, традиційна форма навчання має звужені рамки застосування. Крім того, саме тренінг дає можливість «занурення» учасників в тему на певний час, коли вони повністю зосереджені на тому, що вивчається.

Тренінгові форма навчання має такі переваги:

- забезпечує високу активність групи за рахунок комфортної атмосфери навчання;

- дає можливість поєднання засвоєння інформації 3 формуванням емоційного ставлення до неї;

- значно підвищує рівень мотивації студентів до професійної діяльності;

- створює можливості до колективного мислення та прийняття рішень;

- дозволяє практично перевірити та закріпити отримані знання, уміння, навички.

Слабкими сторонами тренінгу є те, що:

- ця форма непридатна для подання великого обсягу суто теоретичного матеріалу (формул, історичних відомостей тощо);

- має бути відносно невелика група;

- теоретична підготовка членів групи має бути близькою за рівнем;

- потрібна більша майстерність викладача, оскільки учасники можуть по-різному усвідомлювати тренінгові вправи. 
Так само, як і будь-яке навчальне заняття, тренінг також має певну мету:

- інформування та набуття учасниками тренінгу нових навичок та умінь;

- опанування нових технологій;

- зменшення чогось небажаного (прояв поведінки, стилю, неефективного спілкування, особливостей реагування тощо);

- зміна погляду на процес навчання як такий, що може приносити наснагу та задоволення:

- підвищення здатності учасників до позитивного ставлення до себе та життя:

- пошук ефективних шляхів розв'язання поставлених проблем завдяки об'єднанню в тренінговій групі різних за характером, темпераментом, емпіричним досвідом, знаннями, уміннями та іншими якостями студентів, які у процесі обговорення впливають на розв'язання зазначеної проблеми.

Тренінг - це водночас і цікаве спілкування, і захопливий процес пізнання себе та інших, i ефективна форма опанування знань, розширення досвіду, і спосіб формування вмінь та навичок. У сучасній педагогічній літературі поняття «тренінг» трактується набагато ширше, ніж навіть кілька років тому. Розширення меж використання терміна пов'язано зі збільшенням діапазону цілей,більш широкого, ніж розвиток компетентності у спілкуванні.

Нині тренінг - це і спеціальна форма організації навчальної діяльності, що переслідує конкретні й прогнозовані цілі, які можуть бути досягнуті у відносно короткий термін, і спосіб навчання учасників і учасниць та розвиток у них необхідних здібностей та якостей, що дозволяють досягти успіху в певному виді діяльності, і інтенсивне навчання, що досягається спеціальними інтерактивними вправами. Таким чином поняття треніг поєднує і підходи до організації навчання і власне методи, поєднання яких власне і визначає заняття як тренінгове.

Готуючись до проведення тренінгу, викладач має здійснити велику підготовчу роботу:

- визначити цілі та завдання тренінгу;

- розробити план тренінгу;

- підготувати заздалегідь студентів до проведення тренінгу (роздати питання, що будуть розглядатися на тренінгу, проблеми, які будуть обговорюватися, літературу для попереднього опрацювання тощо);

- здійснити самопідготовку: продумати власні дії щодо проведення інтерактивної взаємодії, передбачити план обговорення проблеми та можливі висновки, що зроблять педагоги, спрогнозувати появу суперечних точок зору та кінцевий результат роботи, обрати час і форми узагальнення висновків, продумати зворотний зв'язок та ін.;

- розподілити ролі між учасниками, продумати активну участь кожного;

- підготувати приміщення до проведення тренінгу та необхідні матеріали (медіапроектор, бейджики, таблички, скотч, папір для індивідуальних та групових вправ, маркери, роздруковані матеріали для вивчення тощо). Якість навчання суттєво зростає, якщо слухачі мають хороші роздаткові матеріали.

Важливим фактором $є$ підготовка матеріалів у тому форматі, що легко читається, а саме:

- лаконічні тексти;

- можливі чіткі схеми замість деяких текстових блоків;

- малюнки;

- можливість робити помітки у цих матеріалах.

Залежно від цілей, тренінг може використовуватися в навчанні студентів у різних цілях:

- як тренування, у результаті якого відбувається формування та відпрацювання вмінь та навичок, ефективної поведінки;

- як форма активного навчання, метою якого є передусім передання знань, а також розвиток деяких умінь і навичок;

- як метод створення ситуацій для саморозкриття учасників і самостійного пошуку ними способів вирішення власних психологічних проблем.

- як форма розвитку готовності майбутнього педагога до формування самоосвітньої компетентності учнів дає змогу: у цікавій і доступній формі оволодівати знаннями, вміннями, необхідними для створення такого освітнього середовища і взаємодії на всіх рівнях, які сприятимуть становленню відповідної мотивації до самоосвіти, забезпеченню успішної пізнавальної діяльності через формування і вдосконалення необхідних загальнонавчальних умінь; формувати у самого майбутнього вчителя відповідальне ставлення до процесу керівництва самоосвітою учнів тощо. 
В основу тренінгу покладено групову взаємодію-інтеракцію, для якого характерна:

- групова робота;

- психологічна допомога учасникам групи в саморозвитку, що ініціюється не лише тренером, а й власне учасниками;

- певна просторова організація (найчастіше робота у одному і тому ж приміщенні, коли учасники більшу частину часу сидять у колі);

- взаємовідносини між учасниками групи розвиваються і аналізуються в ситуації «тут і зараз»;

- застосування активних методів групової роботи;

- вербалізована рефлексія з приводу власних почуттів і того, що відбувається в групі;

- атмосфера розкутості й свободи спілкування між учасниками, клімат психологічної безпеки.

Залежно від цілей, тренінг може використовуватися в навчанні студентів у трьох формах:

- тренінг як тренування, у результаті якого відбувається формування та відпрацювання вмінь та навичок, ефективної поведінки.

- тренінг як форма активного навчання, метою якого $є$ передусім передання знань, а також розвиток деяких умінь і навичок.

- тренінг як метод створення ситуацій для саморозкриття учасників і самостійного пошуку ними способів вирішення власних психологічних проблем.

При проведенні тренінгу використовуються різноманітні конкретні вправи, прийоми i техніки. Визначають такі базові методи тренінгу: групова дискусія та ситуативно-рольові ігри.

Дискусія - це спосіб організації спільної діяльності з метою інтенсифікації процесу прийняття рішення у групі; метод навчання, що підвищує інтенсивність та ефективність навчального процесу за рахунок залучення тих, хто вчиться, до колективного пошуку істини.

Групова дискусія - це спільне обговорення якогось суперечливого питання, що дає змогу прояснити або змінити думки, позиції та настанови учасників групи у процесі безпосереднього спілкування.

Дискусія побудована на діалозі - такій формі спілкування, що грунтується на психологічній рівності позицій учасників обговорення.

У тренінгу групова дискусія може бути організована 3 метою надання учасникам можливості обговорити проблему, що цікавить усіх, із різних боків, або ж із метою здійснити групову рефлексію через аналіз індивідуальних переживань.

Ігрові методи ведення тренінгів сприяють інтенсифікації процесу навчання, знаттю напруження та скутості учасників, оптимізації їхньої взаємодії. Гра допомагає людині розкрити свої здібності, виявити творчий потенціал, проявити щирість та відкритість.

За характером процесів ігри поділяються на три основні категорії:

- ділові (імітаційне моделювання реальних механізмів і процесів);

- організаційно-діяльнісні (форма колективної мисле діяльності, у процесі якої відбувається навчання і проектування нових діяльнісних зразків);

- рольові (моделювання життєвих ситуацій, розігрування певних проблемних ситуацій).

Ділова гра відбувається через моделювання різноманітних педагогічних чи виробничих ситуацій.

Моделювання - це метод дослідження певних об'єктів через відтворення їхніх характеристик на іншому об'єкті - моделі, що є аналогом певного фрагменту дійсності (речового чи розумового) - оригіналу моделі.

Модель реалізується через правила. Правила гри - це ті положення, в яких відбиваються сутність гри та співвідношення всіх іiі компонентів. Ділові ігри складаються 3 певних етапів підготовки і проведення.

Ділова гра є способом моделювання різноманітних умов професійної діяльності через пошук нових засобів ії виконання. Вона імітує різноманітні аспекти людської активності й соціальної взаємодії, є методом ефективного навчання, оскільки нівелює суперечності між абстрактним характером навчального предмета і реальним характером професійної діяльності.

Ділова гра як метод містить інші форми активного навчання: дискусію, аналіз конкретних ситуацій, дії за інструкцією, розв'язання виробничих завдань тощо. Вона дає змогу знайти рішення складних проблем шляхом застосування спеціальних правил обговорення, стимулювання творчої активності учасників як завдяки спеціальним методам роботи, так і за допомогою модерації тренера.

Рольова гра - це ефективне відпрацювання варіантів поведінки в тих ситуаціях, в яких можуть опинитися учасники тренінгу (наприклад, захист чи презентація певних напрацювань, 
атестація тощо). Гра дає можливість набути навичок прийняття відповідальних і безпечних рішень у житті.

Підготовка до проведення рольових ігор:

1. Гра повинна бути значущою для учасників.

2. Попереднє діагностування слухачів необхідне для вибору ситуацій, рішення яких можливе в межах одного заняття.

3. Важливим $\epsilon$ вибір учасників гри. Керівник рольової гри, зазвичай, не $\epsilon$ безпосереднім учасником ігрового комплексу.

Організаиійно-діяльнісні та організаційно-навчальні ігри є формами колективної розумової діяльності, у процесі якої відбувається навчання і проектування (створення) нових діяльнісних зразків.

Однією з ефективних форм інтерактивного навчання є кейс-метод. Ті, хто вчиться, вбачають у ньому гру, в якій вони мають можливість проявити та вдосконалити аналітичні й оцінювальні навички, навчитися працювати в команді, використовувати на практиці теоретичний матеріал тощо.

Кейс-метод (case study) - це техніка навчання, що користується описом реальних економічних $\boldsymbol{i}$ соціальних ситуацій (від англ. саsе - «випадок»). Під ситуацією (кейсом) розуміють письмовий опис конкретної реальної події в закладі, слухачам пропонують проаналізувати іiі, знайти шляхи розв'язання та обрати найкращу з них. Ситуаційна вправа, що розглядається, повинна бути побудованою на реальна подіях.

Кейс-метод, або метод ситуаційних вправ, є активним методом, що дає змогу наблизити процес навчання до реальної практичної діяльності спеціалістів. Він сприяє розвитку винахідливості, умінню вирішувати проблеми, розвиває здібності здійснювати аналіз і діагностику проблем.

Кейс-метод - складна система, що інтегрує в собі інші методи пізнання: дискусію, ігрові методи, «мозковий штурм», моделювання, мисленнєвий експеримент, проблемний метод, системний аналіз тощо.

Проблема посідає важливе місце в кейс-методі, при цьому в самому кейсі вона часто $\epsilon$ присутньою в неявному, замаскованому вигляді, нерідко буває прихованою серед інших, менш вагомих проблем, розгляд яких може повести дискусію не в той бік.

Згадані вище методи і прийоми, що використовуються під час проведення тренінгу, можуть бути значною мірою розширені, адже тренінг передбачає комплексне використання різноманітних методів і прийомів навчання, що стимулюють активну пізнавальну позицію слухачів, спонукають їх до взаємодії, взаємонавчання. Інтерактивне навчання у практиці професійного навчання $\epsilon$, без сумніву, перспективним напрямом української педагогіки.

\section{ЛIТЕРАТУРА}

1. Авдеєва І. М. Інноваційні комунікативні технології в роботі куратора академгрупи: навч. посіб. Київ: Професіонал, 2007. 304 с.

2. Емельянов Ю. Н. Активное социально-психологическое обучение. Львов: ЛГУ, 1985. 168 с.

3. Ковалев Г. А. Основные направления использования методов активного социального обучения в странах Запада. Психологический журнал. 1989. Т. 2, № 1. С. 127-136.

4. Макшанов Г. И. Психология тренинга. СПб., 1997. 238 с.

5. Освітні технології / за. ред. О. М. Пєхоти. Київ, 2001. 455 с.

6. Парыгин Б.Д. Социальная психология: проблемы методологии, истории и теории. СПб.: ИГУП, 1999. -592 c.

7. Петровская Л. А. Компетентность в общении: социально-психологический тренинг. Москва: Изд-во Моск. Ун-та, 1990. 430 с. 